\title{
Safety barrier of electrical equipment for environments with a potential explosion in underground coal mines
}

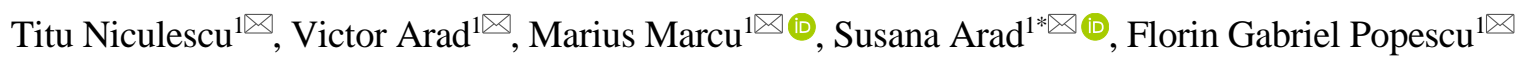 \\ ${ }^{1}$ University of Petrosani, Petrosani, 332006, Romania \\ *Corresponding author: e-mail susanaarad@yahoo.com, tel.+40727759474
}

\begin{abstract}
Purpose. Electrical equipment for explosion-threatening environments in mines at risk of explosion communicates with the external environment through intrinsic safety barriers that limit the values of currents to values below the methane ignition, limit that exceeds the allowable concentration in the atmosphere. This avoids work accidents due to under-ground explosions, avoiding the risk of explosion through electric equipment.
\end{abstract}

Methods. Experimental research has been based on the geomechanical characterization of the coal and surrounding rocks in the Jiu Valley Basin and measurements obtained in situ was researched by statistic methods. Three methods of studying barriers based on the use of the MATLAB program were used. The first method is based on MATLAB programming, the second involves the barrier study using the Simulink model and the third method is based on the use of the SimPowerSystems software package. In all three cases studied, the variation of the voltage at the output of the barrier and current through the barrier are analyzed considering two operating modes, the aperiodic and the oscillating regimes.

Findings. The paper is a study of the intrinsic security barriers, based on which a correct dimensioning can be made.

Originality. The originality of the paper consists in the analysis of the barriers with intrinsic safety, using the simulation with the MATLAB-Simulink program packages.

Practical implications. All the methods addressed lead to obtaining the diagrams of variation of the voltage at the exit of the barrier and of the current through the barrier in two possible regimes: the aperiodic regime and the oscillating regime.

Keywords: coal mining, explosive environment, gas explosions, geomechanical parameters, methane, security barrier

\section{Introduction}

Jiu Valley coal basin represents one of the most important mining areas in Romania. In Jiu Valley coal Basin the coal extraction activity is realized in difficult specific conditions: (i) the extremely complicated tectonic, the deposit being divided in small dimensions blocks, delimited by faults, with tectonic anomalies and lens form effilated; (ii) methane and coal dust presence, constituting a highly explosive environment in the exploited sectors; (iii) the selfcombustion proprieties of the coal pit in the oxygen's presence, generating mine fires.

Development and exploitation of coal deposits requires social acceptance, diminution of environmental impact and avoiding the risk of explosion which can be assessed, modeled, and mitigated [1]. The causes of accidents in coal mining can be classified as follows:

1. Falls of Roof (Coal, Rock, etc.).

2. Falls of Face or Pillar Coal.

3. Mine Cars and Locomotives.

4. Gas Explosions and Burning Gas.

5. Coal Dust Explosions (including gas and dust combined).
6. Explosives.

7. Suffocation from Mine Gases.

8. Electricity.

10. Mining Machines.

11. Mine Fires (burned, suffocated, etc.).

12. Other Causes.

The coal mine technical staff must be able to identify the risks that lead to underground mine gas explosions, and implement practical strategies to optimize mining safety for workers. Some of these "accidents" may be due to the defective mentality of the workers, but most of them are directly traceable to the technical conditions and of ignoring work safety measures. Accidents credited to carelessness, neglect and ignorance of the workers should be analyzed and the coal-miners should be periodically subjected to the now usual tests to ascertain the power of their senses, their quickness of perception, their capacity of judgment and the rules of the labor safety, etc. [2].

The most serious accidents from the coal exploitation in the Jiu Valley Basin were the combination of causes: Coal Dust Explosions (including gas and dust combined) with electricity sources. 


\subsection{Technical considerations regarding methane emissions}

Effective management of methane risks from coal mines can also have the benefit of contributing to reduced or minimized greenhouse gas GHG emissions. Good safety practice in coal mines is to reduce explosion risk by preventing the occurrence of explosive mixtures where practical, and by rapidly diluting them to safe concentrations (through ventilation systems). Gas flows from underground coal mines under normal, steady-state conditions are relatively predictable in certain geological and mining conditions, although there is significant variation from country to country. A lack of reliable gas emission prediction methods for deep and multiple-seam mining continues to be a significant challenge due to the complex mining-induced interactions between strata, groundwater and gas. Nonetheless, numerical methods for projecting gas flows, gas capture, ventilation requirements and utilization potential are available and should be used routinely in mine planning [3][4].

Due to the complex interactions of parameters related to explosion type events, the atmospheres which carry this risk type impose the multidisciplinary methods for detecting the conditions which converge to the ignition point of the phenomenon. Understanding the processes developed before, during and after the initiation of an explosion, may lead to future avoidance of such events, by adopting proper measures for each situation. The prediction of methane emission magnitude and shape is very important when assessing the air flow quantities required for ventilation purposes, in order to establish the proper technical measures aiming the prevention of dynamic gas emission occurrence [5]. The presence of coal bed methane in Jiu Valley hard coal deposit was revealed during prospection, opening, preparation and exploitation workings carried out [6].

For this purpose, numerous researches have been done based both on experimental studies and modeling on materials equivalent to the potentially explosive environment in the underground of the Jiu Valley mining basin and not lastly simulations with the help of dedicated software or software environments (SURPAC, ANSYS, 3D-CHANGE, etc.) [7][8].

From the observations and measurements carried out underground a zoning of the methane emissions in the basin issued with a maximum value in the western-central area: Livezeni, Paroseni, Lupeni and on the deposit's a maximum magnitude in the depth (3, 5, 8, 9 and 13 seams) [6].

Experimental research has been based on the geomechanical characterization of the coal and surrounding rocks in the Jiu Valley Basin. The physical and the mechanical properties of rocks and coals are also influencing both the migration and the release of methane.

With respect to the geomechanical properties that have been determined for the rocks in the Jiu Valley (See table 1), their values are having an increasing trend from the Eastern part to the western part of the basin, due to the different metamorphism degree and in relation to the type of rock.

The analysis of results gained for the physical and mechanical properties of coals in the Jiu Valley (Table 1) [6] shows a great diversity depending on the mining field and differences among the coal seams tectonics, to the petrographic components, to the direction of stress, etc.

The results regarding the physical, mechanical and elastic properties of rocks in the Jiu Valley coal basin have been correlated with the measurements carried out in situ and the laboratory testing for the rocks neighboring the coal beds to be mined.

Table 1. Average values of the physical, mechanical and elastic characteristics of seam's 3 coal and rocks

\begin{tabular}{|c|c|c|c|c|c|c|c|}
\hline Name & $\begin{array}{l}\text { Bulk density, } \\
\gamma, 10^{4} \mathrm{~N} / \mathrm{m}^{3}\end{array}$ & $\begin{array}{l}\text { Specific density, } \\
\gamma_{a}, 10^{4} \mathrm{~N} / \mathrm{m}^{3}\end{array}$ & $\begin{array}{l}\text { Porosity, } \\
n, \%\end{array}$ & $\begin{array}{c}\text { Compression } \\
\text { strength, } \sigma_{r c}, \\
\text { daN/cm }{ }^{2}\end{array}$ & $\begin{array}{l}\text { Cohesion, } \\
C, \mathrm{daN} / \mathrm{cm}^{2}\end{array}$ & $\begin{array}{c}\text { Elasticity modulus, } \\
E, \mathrm{daN} / \mathrm{cm}^{2}\end{array}$ & $\begin{array}{l}\text { The Poisson } \\
\text { ratio, } \mu\end{array}$ \\
\hline Coal & 1.45 & 1.31 & 9.7 & 95 & $11-25$ & $5.300-16.000$ & 0.17 \\
\hline $\begin{array}{l}\text { Direct } \\
\text { roof rocks }\end{array}$ & 2.65 & 2.58 & 3.5 & 441 & 60 & 51.000 & 0.2 \\
\hline $\begin{array}{l}\text { Main } \\
\text { roof rocks }\end{array}$ & 2.67 & 2.60 & 2.6 & 1.280 & 205 & 55.000 & 0.12 \\
\hline
\end{tabular}

Permeability is the capability of certain porous media to allow the free circulation of fluids and of gases through they voids. This capability has been materialized by Darcy through the value of the permeability coefficient $K_{p}$.

There were carried out measurements of the permeability coefficient in two mine workings from Livezeni Colliery and Paroseni where there were carried out several drillings. In Table 2 we can see the results.

\subsection{Dependence between properties of rocks and methane gas emissions}

The use of analytical methods shall take into consideration the aspects that have been underlined after performing of the qualitative analysis. The elementary statistics methods can reduce the large number of data through experimental measurements up to a useful form by defining the distribution type and determining the unique value that represents the best the central value of distribution and determining the variation from the average value - standard deviation. In this respect we used statistical methods for analyzing of dependence between some properties of rocks and emission gaseous [6][9].
Table 2. Results of the measurements regarding the permeability coefficient

\begin{tabular}{|c|c|c|c|c|}
\hline Colliery & Location & $\begin{array}{l}\text { Length of } \\
\text { gallery, m }\end{array}$ & $\begin{array}{c}\text { Permeability } \\
\text { coefficient, } \\
K, \mathrm{~m} / \mathrm{s}\end{array}$ & $\begin{array}{c}\text { Gas } \\
\text { pressure, } \\
P, \mathrm{MPa}\end{array}$ \\
\hline \multirow{8}{*}{ Livezeni } & \multirow{8}{*}{$\begin{array}{l}\text { Main gallery, } \\
\text { panel 1, seam } \\
3 \text { block VI A }\end{array}$} & 45 & $1.93 \cdot 10^{-12}$ & 0.19 \\
\hline & & 54 & $1.97 \cdot 10^{-12}$ & 0.19 \\
\hline & & 64 & $1.64 \cdot 10^{-12}$ & 1.16 \\
\hline & & 73 & $2.05 \cdot 10^{-12}$ & 0.38 \\
\hline & & 82 & $7.09 \cdot 10^{-13}$ & 0.388 \\
\hline & & 90 & $3.62 \cdot 10^{-13}$ & 0.77 \\
\hline & & 97 & $8.53 \cdot 10^{-13}$ & 0.38 \\
\hline & & 106 & $12.18 \cdot 10^{-13}$ & 0.38 \\
\hline \multirow{8}{*}{ Paroseni } & \multirow{8}{*}{$\begin{array}{l}\text { Base gallery, } \\
\text { panel } 2 \text {, seam } \\
3 \text {, block VI A }\end{array}$} & 80 & $0.42 \cdot 10^{-12}$ & 0.58 \\
\hline & & 88 & $2.66 \cdot 10^{-12}$ & 0.77 \\
\hline & & 98 & $2.04 \cdot 10^{-12}$ & 0.58 \\
\hline & & 107 & $10.53 \cdot 10^{-13}$ & 0.38 \\
\hline & & 116 & $3.41 \cdot 10^{-12}$ & 1.35 \\
\hline & & 126 & $5.24 \cdot 10^{-12}$ & 0.97 \\
\hline & & 135 & $4.16 \cdot 10^{-12}$ & 2.72 \\
\hline & & 140 & $1.37 \cdot 10^{-12}$ & 1.16 \\
\hline
\end{tabular}




\subsubsection{Dependence between porosity and methane concentration}

We used statistical software for analyzing of dependence between porosity and methane concentration for the surrounding rocks. The first statistical correlation is based on the polynomial equation, given by the Equation (1):

$y=\frac{a+b x+c}{\ln x}+\frac{d}{x^{0.5}}+\frac{e}{x^{2}}$,

which had a good correlation coefficient $r^{2}=0.911735676$.

Figure 1 shows the dependence between porosity and methane concentration for the surrounding rocks and Figure 2 shows the diagram between porosity and methane flow in $\mathrm{m}^{3} / \mathrm{t}$ for the coal energy and it is expressed by the Equation (2):

$y=a+b \cdot \sin \left(\frac{2 \pi x}{d+c}\right)$.

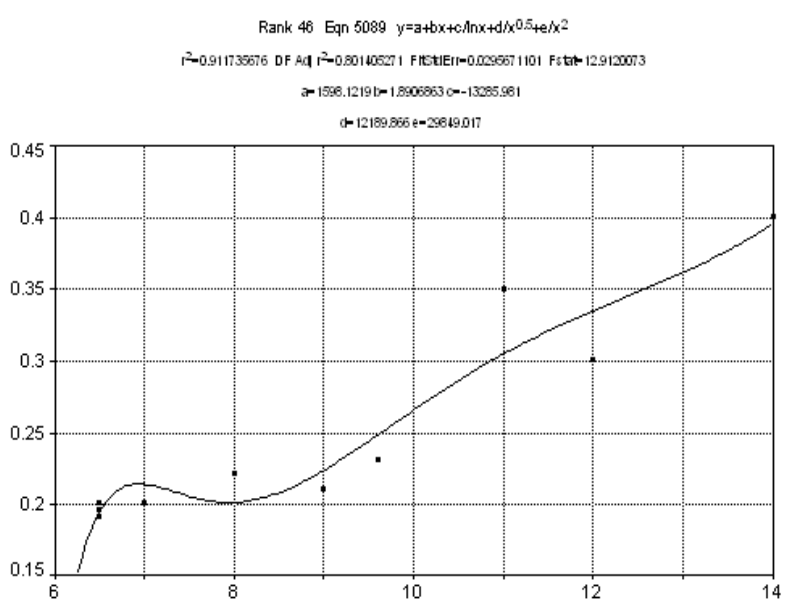

Figure 1. Dependence between porosity and methane concentration in surrounding rocks

Rank 1 Eqn $8014 \mathrm{y}=\mathrm{a}+\mathrm{b} \sin (2 \pi x / \mathrm{d}+\mathrm{c})$ [Sine]

$r^{2}=0.763260357$ DF Adj $r^{2}=0.447607499$ FitStdE $r r=2.04590802$ Fstat $=4.29873283$ $a=8.8048575 b=3.4557717$

$c=1.6250398 \mathrm{~d}=5.4221012$

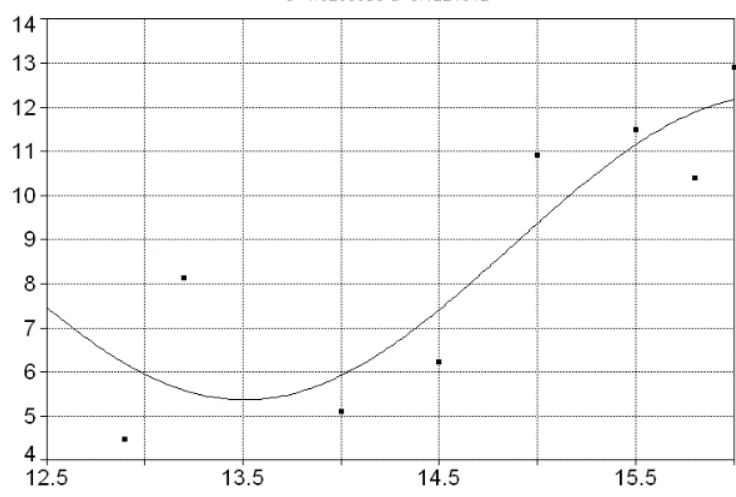

Figure 2. Porosity and methane flow for coal steam

\subsubsection{Dependence between permeability} and methane concentration

The variation of methane concentration in relation with the permeability is being described by the exponential Equation (3) for the surrounding rock:

$$
y=\frac{a+b x+c x^{2}+d}{x}+\frac{e}{x^{2}} .
$$

The coefficient of correlation is $r^{2}=0.45210819$.

Figure 3 shows how methane concentration in percent alters in relation to permeability in $\mathrm{m} / \mathrm{s}$.

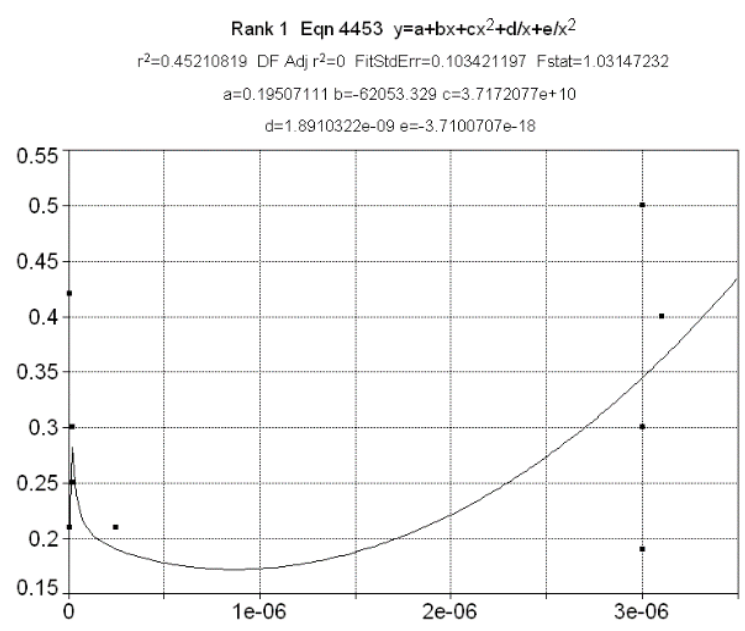

Figure 3. Dependence between permeability and methane for the surrounding rock

The variation of methane flow $\left(\mathrm{m}^{3} / \mathrm{t}\right)$ in relation with the permeability $(\mathrm{m} / \mathrm{s})$ for coal energy is being described by the exponential Equation (4) and is shown in Figure 4:

$y=a+b^{-\frac{x}{c}}$.

Rank 1 Eqn 8002 y=a+bexp(-x/c) [Exponential]

$r^{2}=0.676326059$ DF Adj $r^{2}=0.433570603$ FitStdErr $=2.13968318$ Fstat $=5.22382229$ $=-2.0184387 \mathrm{~b}=4.023873$ $c=-1.7922551 \mathrm{e}-06$

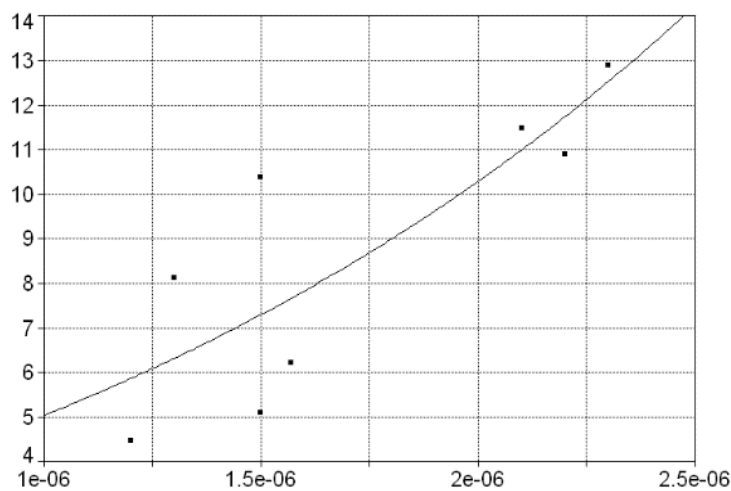

Figure 4. Dependence between permeability and methane flow for coal energy

During the coal extraction process, as a consequence of several natural and technological parameters, various methane amounts are released, generating in certain specific conditions significant risk-related problems for the underground working environment [3].

From measuring we observed that most violent methane emissions occurred at Lupeni and Paroseni mining fields where more than $90 \%$ of the drill holes, methane behaved in one of the above mentioned forms. 
In conclusion it can be said that we have determined statistical correlation among the properties of rocks (permeability and porosity) and the ones of coals and methane emissions that were measured in natural conditions in situ, determined in the Geomechanics Lab at the University of Petrosani. All these dependences were confirmed based on the variation trend issued from observations made over this phenomenon and on experimental testing and not necessarily in relation to the coefficient of correlation [10].

In order to implement the environmental policy related to the coal mining activity, it is necessary to monitoring many factors alongside the methane emissions. Computers, using specialized applications for the mining ventilation, can assist this process [11].

\subsection{Equipment used in the ATEX explosive atmosphere}

In areas with potential explosion danger, only electrical equipment and materials that comply with the ATEX 100a directive are admitted. European Directive 94/9/EC (ATEX 100a) has been specifically approved to standardize explosion protection methods by the treaty established between the European Community and the Member States. It specifies the requirements regarding the characteristics required for explosion-protected equipment and systems as specified in Article 100a. This is where the term ATEX 100a also comes from. The Directive applies to all industrial environments with explosive potential, including underground coal mining (including dust protection). Mechanical equipment, which operates in explosion hazardous areas, can also be hazardous sources. They will have to be modified in design, size and positioning, so that they do not present danger, even in the event of malfunctions.

The exploitation of coal in these conditions is a permanent challenge for the equipment to be used in these explosive environments. In order to use the equipment in the coal mines, which are in danger of explosion, these equipments must comply with the security technical norms and the ATEX requirements [4].

Electrical equipment for explosion-threatening environments in coal mines communicates with the external environment through intrinsic safety barriers that limit the values of currents through barriers to values below the methane ignition limit that exceeds the allowable concentration in the atmosphere. Thus avoiding the occurrence of underground explosions in the activity of coal extraction, explosions that are the most common causes of accidents at work underground.

\section{The mathematical model of the barrier}

To analyze the variation of the current through the intrinsic safety barrier and the voltage at its output, an assembly made according to the diagram of Figure 5 in which the uniformly distributed parameters inside and outside the barrier are considered concentrated [12].

In this figure with $\mathrm{R}$ the value of the resistor in the barrier is denoted, $\mathrm{L}$ is the measured or estimated line inductance and with $C$ the capacity of the line outside the barrier. The capacitance of the internal circuit was noted with $\mathrm{Ci}$, this capacitor charging practically instantaneous when applying the step signal [13].

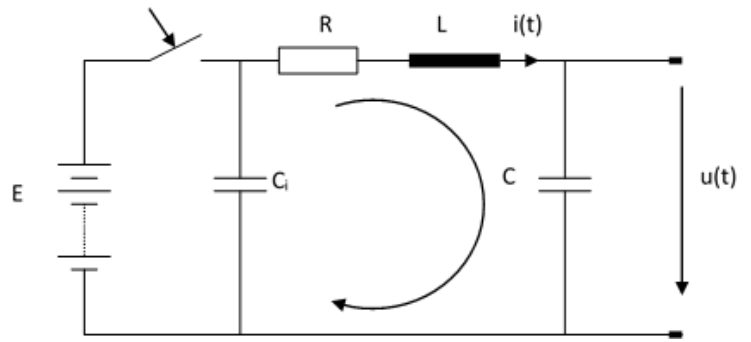

Figure 5. Electrical diagram of the safety barrier when applying the signal step

The variation of the current through the barrier and the variation of the voltage at the exit of the barrier are studied when a step signal is applied at the end of the equipment. The integral-differential equation of the voltages when the circuit is closed is [14]:

$$
R i+L \frac{d i}{d t}+\frac{1}{C} \int i d t=E,
$$

or:

$L C \frac{d^{2} u}{d t}+R C \frac{d u}{d t}+u=E$.

The following notations are done:

$\delta=\frac{R}{2 L}-$ damping of the circuit;

$\omega_{0}=\frac{1}{\sqrt{L C}}-$ pulsation of the circuit;

$\omega=\sqrt{\delta^{2}-\omega_{0}^{2}}-$ pseudo-pulse of the circuit.

We consider the following situations:

a) $\delta>\omega_{0}$ or $R>2 \sqrt{\frac{L}{C}}$, the situation verified by the resistor in the barrier. In these conditions, solving the differential equation leads to the following solutions:

$$
\begin{aligned}
& u(t)=E\left[1-\frac{1}{2 \sqrt{\delta^{2}-\omega_{0}^{2}}}\left(r_{1} e^{r_{2} t}-r_{2} e^{r_{1} t}\right)\right] ; \\
& i(t)=\frac{E}{2 L \sqrt{\delta^{2}-\omega_{0}^{2}}}\left(e^{r_{1} t}-e^{r_{2} t}\right),
\end{aligned}
$$

with $r_{1}$ and $r_{2}$, the roots of characteristic equation:

$$
\begin{aligned}
& r_{1}=-\delta+\omega \\
& r_{2}=-\delta-\omega
\end{aligned} ;
$$

b) $\delta<\omega_{0}$ or $R<2 \sqrt{\frac{L}{C}}$. It makes notation:

$\omega_{0}^{2}-\delta^{2}=\omega^{\prime 2}$

In these conditions, solving the differential equation leads to the following solutions: 
$u(t)=E\left[1-\frac{\omega_{0}}{\omega^{\prime}} \cdot e^{-\delta t} \cdot \sin \left(\omega^{\prime} t+\beta^{\prime}\right)\right]$

$i(t)=\frac{E}{\omega^{\prime} L} e^{-\delta t} \cdot \sin \omega^{\prime} t$,

where:

$$
\beta^{\prime}=\arccos \frac{\delta}{\omega_{0}} .
$$

For the analysis of the intrinsic security barrier, the MATLAB environment was used, in which three different methods of analysis were used. These methods are presented below.

\section{Analysis of the security barrier by programming}

If we consider the voltage $E$ of $24 \mathrm{~V}$, barrier resistance of $1.5 \mathrm{k} \Omega$, the inductance of the cable connected to the equipment $L=10^{-4} \mathrm{H}$ and the evenly distributed capacity of the cable of $10 \mathrm{nF}$, from the Equations (10) and (11) the MATLAB diagrams are obtained below.

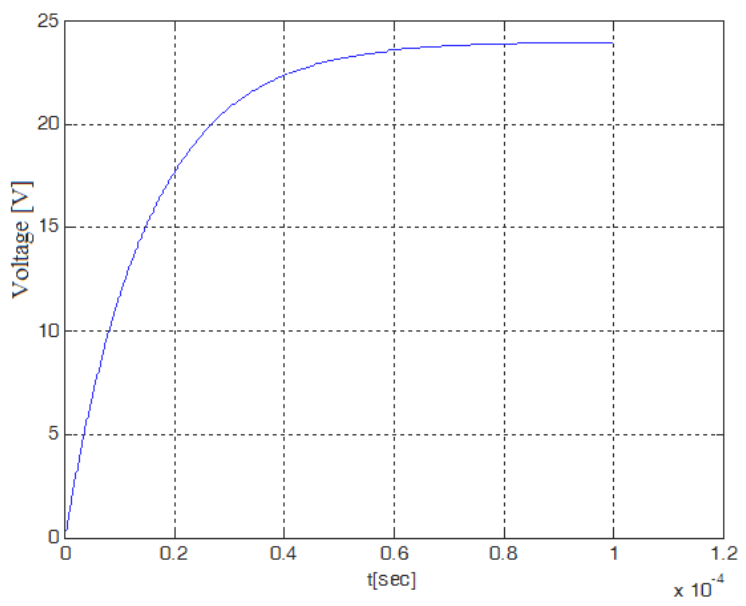

Figure 6. Variation of voltage at the exit of the barrier in the aperiodic regime

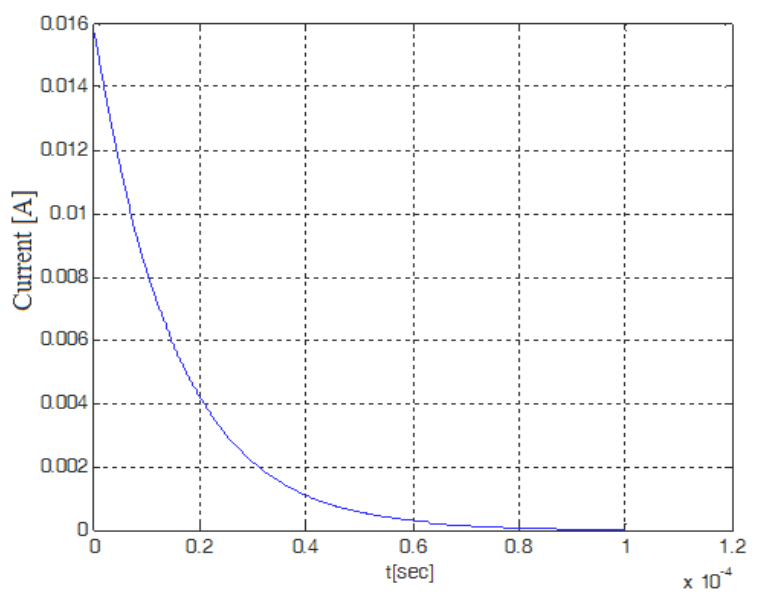

Figure 7. Barrier current variation in the aperiodic regime

If the value of the resistor from the barrier is changed to the value $R=10 \Omega$, the MATLAB diagrams of the voltage at the output of the barrier and of the current through the barrier corresponding to the oscillating regime are obtained (Figs. 8 and 9).

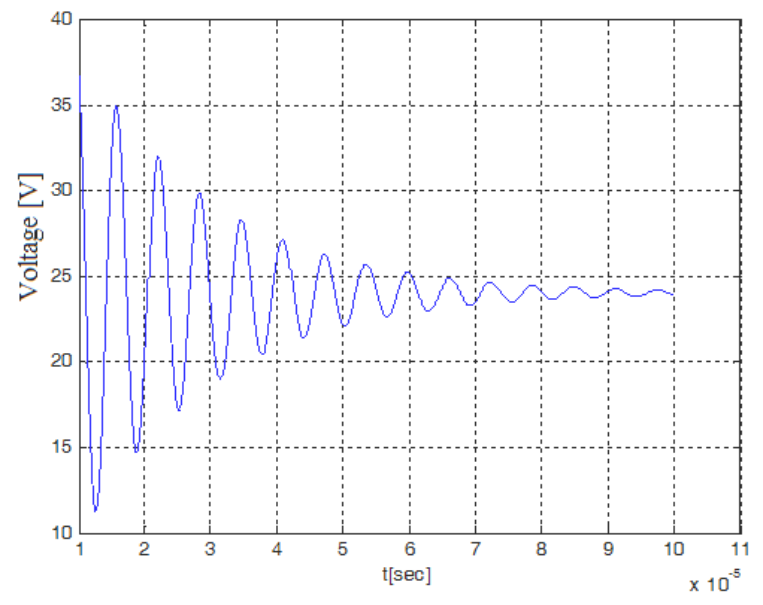

Figure 8. Variation of voltage at the barrier output in the oscillating regime

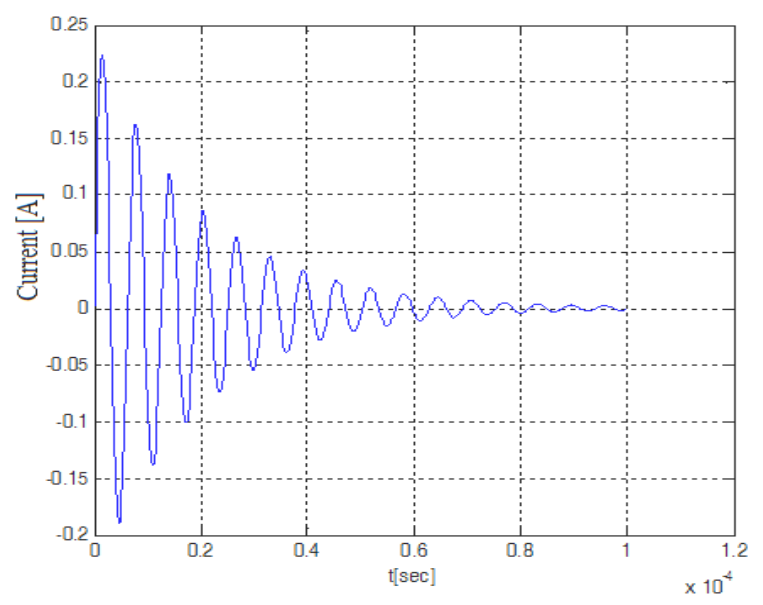

Figure 9. Barrier current variation in the oscillating regime

\section{Security barrier analysis by numerical simulation} form:

The differential Equation (6) can be put in the following

$\frac{d^{2} u}{d t}=\frac{1}{L C}\left[E-R C \frac{d u}{d t}-u\right]$.

Based on this relationship, the Simulink model presented in Figure 10 was designed. This model integrates the differential Equation (6) and shows, for the two cases (aperiodic and oscillating regime) the voltage variation at the barrier output and the current through the barrier diagrams.

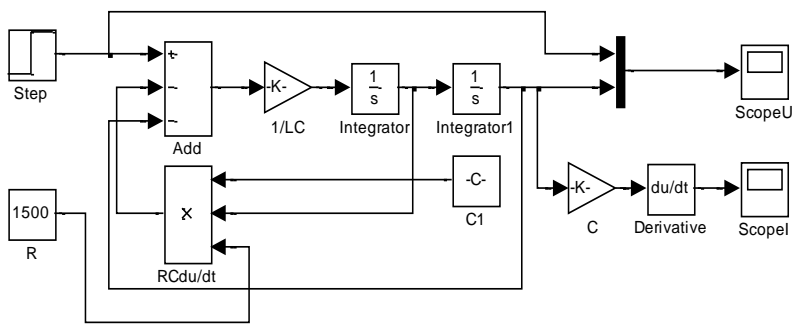

Figure 10. The Simulink model of the security barrier

For the set of values presented above, which corresponds to the case of aperiodic loading, the diagrams of Figures 11 and 12 were obtained. 


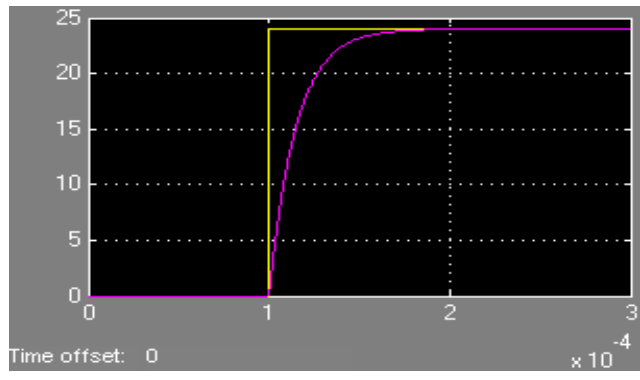

Figure 11. Voltage variation at barrier output

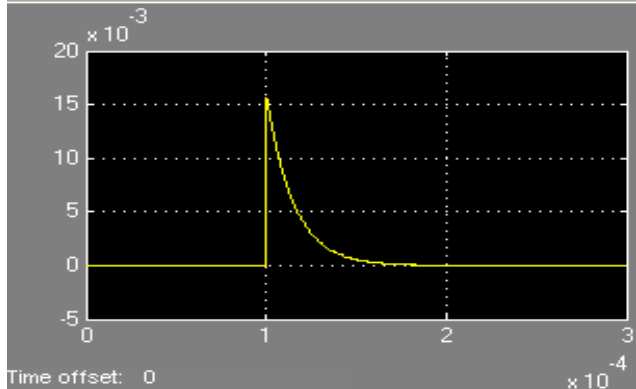

Figure 12. Barrier current variation

For the set of values corresponding to the case of oscillating load, the diagrams of Figures 13 and 14 were obtained.

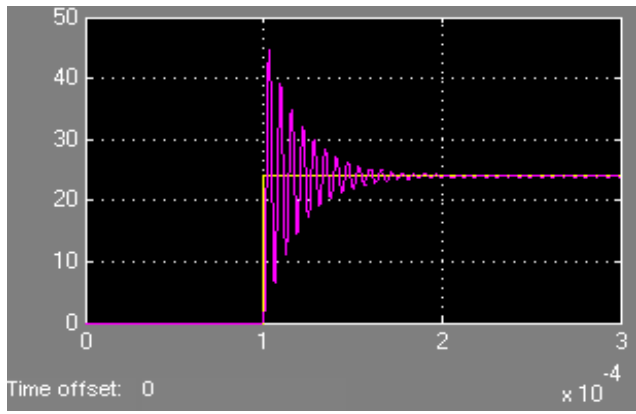

Figure 13. Voltage variation at barrier output

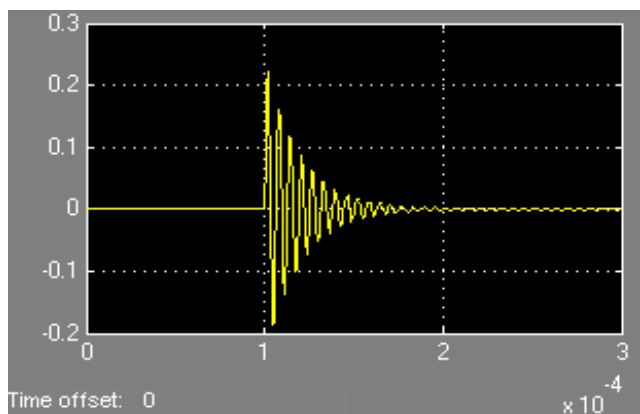

Figure 14. Barrier current variation

\section{Security barrier analysis using the SimPowerSystems software package}

The MATLAB program contains the SimPowerSystems software package with which electrical circuits can be simulated and analyzed in different operating modes. Because the response to the step or impulse signal generates a transient regime, this modality has been used for the behavior of the intrinsic security barrier under these conditions. The simulation model is shown in Figure 15.

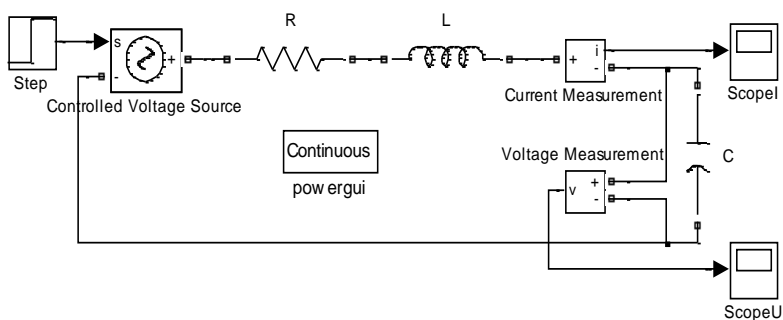

Figure 15. SimPowerSystems model of the security barrier

The advantage of this simulation mode is that the security barrier can be tested at both the unit step signal and the unit pulse and allows to obtain several types of circuit diagrams.

In this situation, two sets of values were also chosen for the circuit parameters, the values used in the study of the barrier by the previous methods.

\subsection{The voltage at the exit of the security barrier}

For the aperiodic charge regime of the capacitor, the voltage variation diagrams were obtained at the output of the barrier, when a step and unit pulse signal is applied to the input. These diagrams are presented below (Fig. 16).

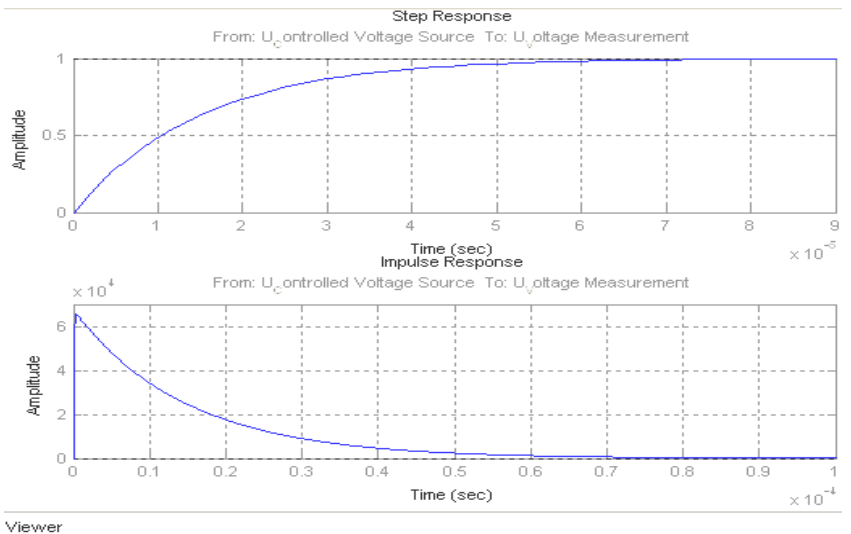

Figure 16. The variation of the voltage at the output of the barrier when applied signal step and impulse in the aperiodic regime

If the set of values of the circuit parameters corresponds to the oscillating regime, the simulation model and the analysis block POWERGUY have led to the following diagrams (Fig. 17).
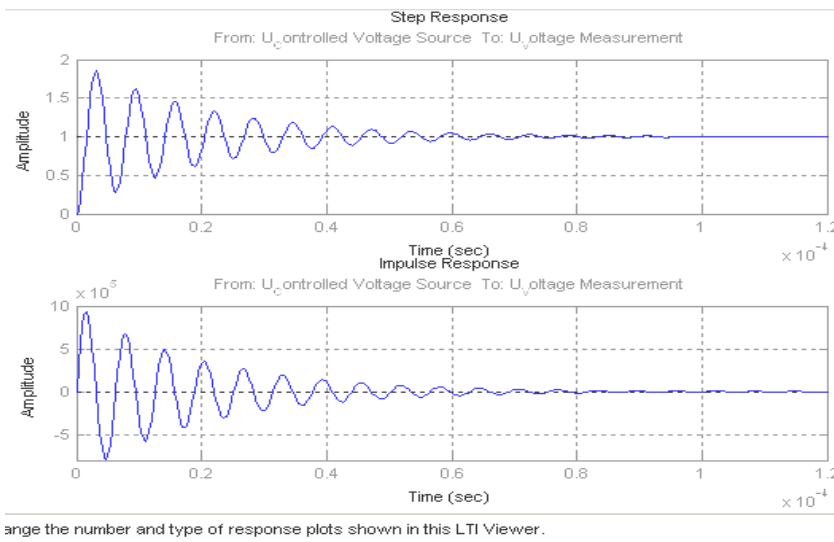

Figure 17. Voltage variation at the barrier output when applied signal step and impulse in the oscillating regime 
The POWERGUY analysis block also allows tracing the frequency characteristics of the voltage at the exit of the barrier (Fig. 18), at which on the horizontal axis is the frequency in logarithmic coordinates (BODE diagram).

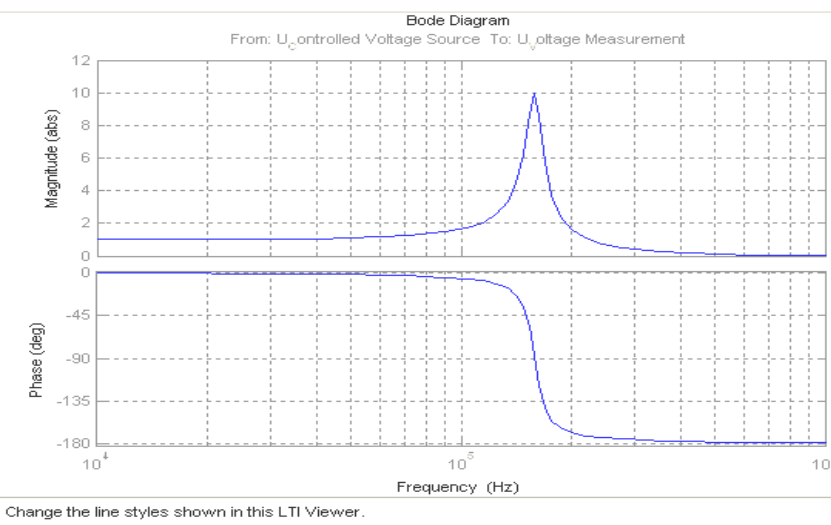

Figure 18. Frequency diagrams of oscillating voltage at the barrier output

\subsection{Variation of current through the security barrier}

The simulation results for barrier current variation are presented in Figures 19-21.

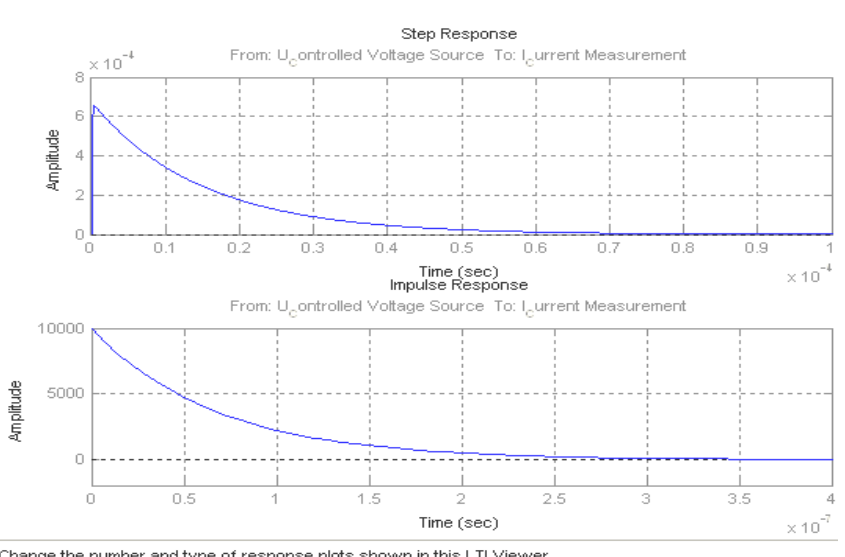

Figure 19. Barrier current variation when applied signal step and impulse in the aperiodic regime
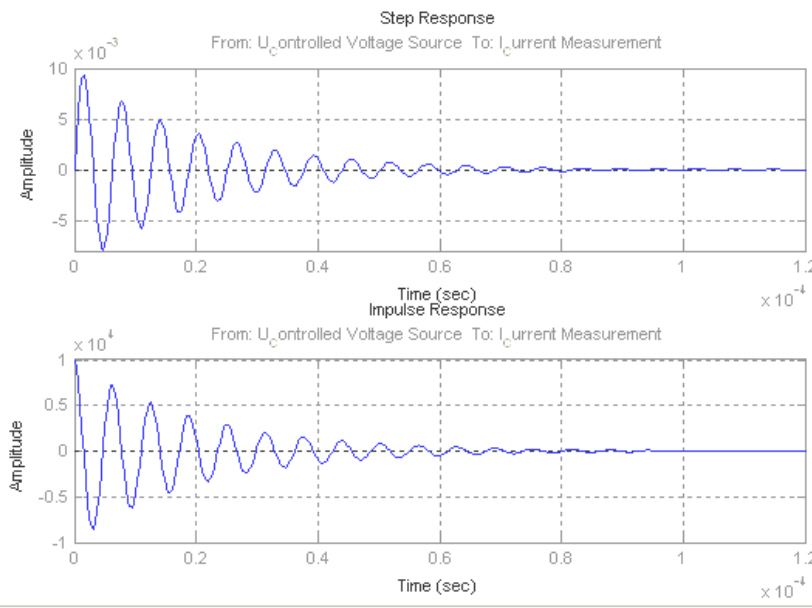

LTI Viewer

Figure 20. Barrier current variation when applied signal step and impulse in the oscillating regime

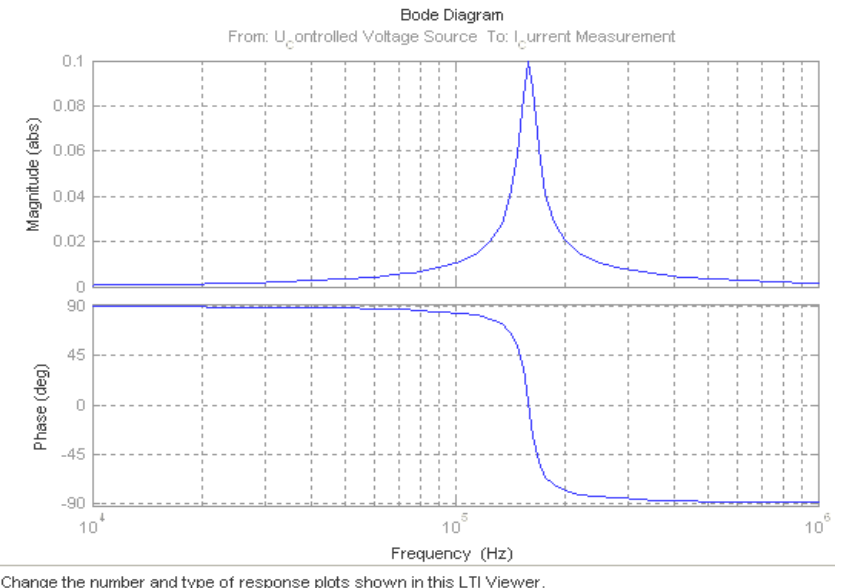

Figure 21. Frequency diagrams of the oscillating current through the barrier

The frequency diagrams of the voltage at the output of the barrier and the current through the barrier highlight the following aspects:

- the voltage at the output of the barrier is maximum at a value of the frequency lower than the resonant frequency of the circuit $f_{0}$ :

$f_{c}=f_{0} \cdot \sqrt{\frac{2-d^{2}}{2}} \cong 1,58 \cdot 10^{5} \mathrm{~Hz}$,

where:

$d=R \sqrt{\frac{C}{L}}=0.1$,

is the damping factor of the circuit.

$U_{C \max }=\frac{U}{d \sqrt{1-\frac{d^{2}}{4}}}=10.01 \mathrm{~V}$,

which is more than about ten times the input voltage (unit step) is the damping factor of the circuit;

- the current intensity through the barrier is maximum at a frequency value equal to the resonant frequency of the circuit:

$f_{0}=\frac{1}{2 \pi \sqrt{L C}} \cong 1.59 \cdot 10^{5} \mathrm{~Hz}$.

At an input voltage frequency of $104 \mathrm{~Hz}$ the current value is:

$$
I=\frac{U}{\sqrt{R^{2}+\left(\omega L-\frac{1}{\omega C}\right)^{2}}} \cong 1 \mathrm{~mA} .
$$

At the resonance frequency through the barrier the current is:

$I_{0}=\frac{U}{R}=0.1 \mathrm{~A}$,

which is one hundred times higher than the current obtained with the Relationship (22). 
The previous calculations were made for the following values of the electrical quantities:

- input voltage: $U=1 \mathrm{~V}$ (unit step);

- line inductance: $L=10^{-4} \mathrm{H}$;

- line capacity: $C=10^{-8} \mathrm{~F}$;

- barrier resistance: $R=10 \Omega$.

\section{Conclusions}

Based on the diagrams obtained in the aperiodic regime and the standards in this domain, a correct dimensioning of the security barriers can be made.

The situation in which the voltage and current through the barrier are oscillating is to be avoided in practice for two essential reasons:

- this regime leads to overvoltage near the supply voltage value, a phenomenon that can be dangerous for the intrinsic security character of the barrier;

- the uniformly distributed reactive elements can generate electrical resonance phenomena, which can lead to overvoltage or overcurrent which may result in the loss of the intrinsic security character of the barrier.

An important conclusion of this study is the way of choosing the value of the barrier resistor which, even if it is based on the ignition curves elaborated by the intrinsic safety standards in the field, it must avoid the oscillating regime described above.

\section{Acknowledgements}

The authors state that this research received no specific grant from any funding agency in the public, commercial, or not-for-profit sectors.

\section{References}

[1] Arad, V., Arad, S., Samoila, L., \& Teseleanu, G. (2019). The coal exploitation in the Jiu Valley between the strategic resource and social impact. Journal of Engineering Sciences and Innovation, 4(1), 99-114.

[2] Bondarenko, V., Symanovych, G., \& Koval, O. (2012). The mechanism of over-coal thin-layered massif deformation of weak rocks in a longwall. Geomechanical Processes During Underground Mining, 41-44. https://doi.org/10.1201/b13157-8

\section{Бар’єр безпеки електричного обладнання для потенційно вибухонебезпечних середовищ вугільних шахт}

\section{Т. Нікулеску, В. Арад, М. Марку, С. Арад, Ф.Г. Попеску}

Мета. Визначення раціональних параметрів бар'єру безпеки електричного обладнання в умовах вибухонебезпечних середовищ вугільних шахт на основі застосування комплексу методів математичного моделювання для запобігати виробничих аварій, пов'язаних з підземними вибухами.

Методика. Експериментальне дослідження засноване на геомеханічній характеристиці вугілля та оточуючих його порід у басейні долини Джиу, а також на даних, отриманих за допомогою натурних вимірювань і оброблених статистичними методами. Були використані три методи вивчення бар'єрів безпеки. Перший заснований на застосуванні програми MATLAB, другий - використовує Simulink моделювання, третій - базується на програмному пакеті SimPowerSystems. У всіх трьох випадках, зміна напруги на вході бар'єру та струм всередині бар'єру розглянуті з точки зору двох робочих режимів - аперіодичного й коливального.

Результати. Визначена та експериментально підтверджена статистична кореляція між властивостями гірських порід і викидами вугілля й метану. Отримано діаграми зміни напруги на вході бар'єру та струм всередині бар'єру в аперіодичному режимі. Виявлено ситуації, в яких напруга і струм через бар'єр коливаються, і яких слід уникати на практиці експлуатації електричного обладнання. Встановлено, що коливання напруги і струму, приводячи до перенапруження поблизу значення напруги живлення, може бути небезпечним для іскробезпечного характеру бар'єру. Визначено, що рівномірно розподілені реактивні елементи можуть генерувати явища електричного резонансу, які можуть сприяти перенапруженню або перевантаженню по струму і можуть привести до втрати іскробезпеки захисного бар'єру.

Наукова новизна. Вперше визначення розмірів бар'єрів безпеки вирішується комплексно із використанням трьох методів математичного моделювання, а результати характеризуються високою точністю.

Практична значимість. Отримано діаграми зміни напруги на вході бар'єру та струм всередині бар'єру з точки зору двох робочих режимів - аперіодичного і коливального, що дозволяє визначити параметри бар'єру безпеки.

Ключові слова: видобуток вугілля, вибухонебезпечне середовище, вибух газу, геомеханічні параметри, метан, бар'єр безпеки 


\section{Барьер безопасности электрического оборудования для потенциально взрывоопасных сред угольных шах}

Т. Никулеску, В. Арад, М. Марку, С. Арад, Ф.Г. Попеску

Цель. Определение рациональных параметров барьера безопасности электрического оборудования в условиях взрывоопасных сред угольных шахт на основе применения комплекса методов математического моделирования для предотвращения производственных аварий, связанных с подземными взрывами.

Методика. Экспериментальное исследование было основано на геомеханической характеристике угля и окружающих его пород в бассейне долины Джиу, а также на данных, полученных при помощи натурных измерений и обработанных статистическими методами. Были использованы три метода изучения барьеров безопасности. Первый основан на применении программы MATLAB, второй - использует Simulink моделирование, третий - базируется на программном пакете SimPowerSystems. Bo всех трех случаях изменение напряжения на входе барьера и ток внутри барьера рассмотрены с точки зрения двух рабочих режимов - апериодического и колебательного.

Результаты. Определена и экспериментально подтверждена статистическая корреляция между свойствами горных пород и выбросами угля и метана. Получены диаграммы изменения напряжения на входе барьера и ток внутри барьера в апериодическом режиме. Выявлены ситуации, в которых напряжение и ток через барьер колеблются, и которых следует избегать на практике эксплуатации электрического оборудования. Установлено, что колебания напряжения и тока, приводя к перенапряжению вблизи значения напряжения питания, может быть опасным для искробезопасного характера барьера. Определено, что равномерно распределенные реактивные элементы могут генерировать явления электрического резонанса, которые могут способствовать перенапряжению или перегрузке по току и могут привести к потере искробезопасности защитного барьера.

Научная новизна. Впервые определение размеров барьеров безопасности решается комплексно с использованием трех методов математического моделирования, а результаты характеризуются высокой точностью.

Практическая значимость. Получены диаграммы изменения напряжения на входе барьера и ток внутри барьера с точки зрения двух рабочих режимов - апериодического и колебательного, что позволяет определить параметры барьера безопасности.

Ключевые слова: добыча угля, взрывоопасная среда, взрыв газа, геомеханические параметры, метан, барьер безопасности

\section{Article info}

Received: 31 March 2020

Accepted: 3 August 2020

Available online: 3 August 2020 